\title{
Ergonomic Analysis of Work-Related Musculoskeletal Risks Associated with Electrical Hazards among Radio and Television Technicians in Enugu State
}

\author{
Ugwoke Chinyere Kate ${ }^{1}$, Ogbuanya Theresa Chinyere ${ }^{2}$, Agbo George Chibuike ${ }^{3, *}$ \\ ${ }^{1}$ Department of Industrial Technical Education, University of Nigeria, Nigeria \\ ${ }^{2}$ School of Education, University of Free State, Bloemfontein, South Africa \\ ${ }^{3}$ Department of Computer \& Robotics Education, University of Nigeria, Nigeria
}

Received February 1, 2021; Revised July 18, 2021; Accepted August 22, 2021

\section{Cite This Paper in the following Citation Styles}

(a): [1] Ugwoke Chinyere Kate, Ogbuanya Theresa Chinyere, Agbo George Chibuike, "Ergonomic Analysis of Work-Related Musculoskeletal Risks Associated with Electrical Hazards among Radio and Television Technicians in Enugu State," Universal Journal of Public Health, Vol. 9, No. 5, pp. 201 - 207, 2021. DOI: 10.13189/ujph.2021.090501.

(b): Ugwoke Chinyere Kate, Ogbuanya Theresa Chinyere, Agbo George Chibuike (2021). Ergonomic Analysis of Work-Related Musculoskeletal Risks Associated with Electrical Hazards among Radio and Television Technicians in Enugu State. Universal Journal of Public Health, 9(5), 201 - 207. DOI: 10.13189/ujph.2021.090501.

Copyright $\bigcirc 2021$ by authors, all rights reserved. Authors agree that this article remains permanently open access under the terms of the Creative Commons Attribution License 4.0 International License

\begin{abstract}
The study aimed at the Ergonomic analysis of work-related musculoskeletal risks associated with electrical hazards among radio and television technicians. The objectives of the study were to determine the factors that facilitate electrical hazard among radio and television technicians, and to examine the factors that prevent electrical hazard among radio and television technicians. The total population of the study was 42 , comprising 24 technicians, 8 workshop attendants and 10 workshop supervisors in radio and television stations in Enugu State Nigeria. Survey research design was adopted. Random sampling was used to select the supervisors. Structured questionnaire containing a total of 18 items was the instrument for data collection. The instrument was validated by three experts and reliability coefficient of 0.89 was obtained using Cronbach's Alpha. The way radio/television stations in Enugu are structured has an impact on how technicians handle working instruments like pliers, screw drivers, chisels, and hammers, as well as other possible workplace hazards like nails, pieces of iron, bare conductors, and so on. There should be a standard building with well labeled shelves where tools and equipment are packed so as to promote their efficiency in the workplace. Technicians should also be aware of specific attitudes they have in the workshop and understand their role in hazard management to ensure that they stay fit
\end{abstract}

and healthy throughout their careers. Occurrence of work related musculoskeletal problems should be minimized among radio/television technicians in Enugu.

Keywords Radio/Television Technician, Workplace, Ergonomic, Work-Related Musculoskeletal Risks

\section{Introduction}

Globally, work related musculoskeletal risks (WMSR) are an occupational problem which electrical maintenance technicians in the radio and television workplace are prone to because of the nature of their job [24]. According to the ILO estimates in 2017, every year over 2.3 million women and men die at work from an occupational injury or disease. Over 350,000 deaths are due to fatal accidents, and almost 2 million deaths are due to fatal work-related injuries. Besides, over 313 million workers are involved in non-fatal occupational accidents causing severe injuries and absences from work. The ILO also estimates in 2017 that 160 million cases of non-fatal work-related injuries occur annually. These estimates imply that every day, approximately 6,400 people die from occupational accidents or diseases and that 860,000 people have 
musculoskeletal disorders.

Work-related musculoskeletal risks (WMSRs) are impairments of body structures such as muscles, joints, tendons, ligaments, nerves, bones or a localized blood circulation system caused or aggravated primarily by the performance of work and by the effects of the immediate environment where the work is carried out Work-related musculoskeletal disorders [1]. It can also arise from a sudden exertion such as lifting a heavy object, or can arise from making the same motions repeatedly or from repeated exposure to force, vibration, or awkward posture over a long period of time [2]. The occurrence of work-related musculoskeletal pain (WRMS pain) among radio/television technicians has been a serious issue because majority of electrical/electronic technician's work are associated with a high risk of injury.

Electrical technicians are personnel trained in Colleges of Education [4] (Technical), Polytechnics and Universities in order to install and repair electrical appliances, electronics, radio and television work competently among others. Radio/Television technicians are those that enter the field by graduating from an accredited technical training program and working for at least a year under an expert, some technicians learn the field through apprenticeships or on-the-job training [3]. Radio/television technicians repairs Radio and TV in a workshop and sometimes due to constantly changing technology of electronics devices and current developments goes to clients' homes to install, modify, repair, maintain and monitor the visual and audio performance of equipment; diagnose equipment failures, correct malfunctions and perform other related duties as required. These technicians play important roles across the globe by creating large quantities of employment opportunities which include outside and bench technicians [4]. Outside technicians make service calls on customers, while bench technicians use test equipment and hand tools in a shop setting to fix problems in the workplace.

Workplace is one of the places other than the home where working years of an individual are mainly spent. Workplace is an ideal place for promoting the health and wellbeing of technicians, a physical location where radio and television technicians carry out their operations [5]. It is a place of learning, development and a route in which any type of knowledge is attained [6] Radio/television technicians make extensive use of their workplaces to train and develop the vocational skills of young people [7]. In his opinion, workplace training has many advantages; it provides a strong learning environment; it improves transition from school to work by allowing employers and potential employees to get to know each other; it contributes to the output of the training firm, and it links training provision to a direct expression of employer' sneeds. In the work place, potentially hazardous machinery should be routinely inspected to ensure safety measures are in place and working properly. Tools should be properly chosen and suitably verified before use. Workplace should be brightly lit and

Extreme temperatures avoided, as well as suitable clothing for assignment tasks provided. Workplace should be strengthened to ensure that technicians stay safe and to reduce the incidence of workplace hazards. Electrical hazard is a risky situation in which technicians may come into electrical contact with energized equipment or a conductor, resulting to a shock, injury, arc flash burn, thermal burn, blast injury among others. Electrical hazards pose a serious threat to worker's safety, many workers are unaware of the potential electrical hazards present in their work environment which makes them more vulnerable to the danger of electrocution and arc flash incidents [8]. In his opinion, unsafe equipment, unsafe acts, and working with live electrical Circuits can lead to electrical accidents and musculoskeletal risks. Electrical hazards are potentially life threatening and found much too frequently in radio/television technicians workplaces.

According to [9], common variables that facilitate electrical dangers include: electrical sparks, short circuits, old wiring in the presence of flammable material, Broken or cracked Plugs, bad fuses, broken or cut cables, Cables run across the floor or walkways without protectors, Extensions /Adaptors not fed from an installed socket point, Ordinary electrical equipment, overloading an equipment, switching wet equipment, improper use of flexible extension cords by radio/television technicians. Some technicians repair cracks, breaks, cuts, or tears with tape instead of discarding the extension cord or shorten it by installing a new plug end [10].Technicians most times overlook work-related practice like separating hand and power tools properly on the shelf, putting on eye goggles, ear muff among others which has the potential of damaging lives. A single accident can mean enormous financial loss to both workers and employers [11], in this opinion; effective workplace practices can help to save the lives of workers by reducing hazards and their consequences. It also has positive effects on both worker's morale and productivity, which are important benefits. For this reason, ergonomic practices in the workplace will helps to optimize the comfort, health, safety and efficiency of the technicians. Ergonomics applies to the design of anything that involves people, workplaces, sports and leisure, health and safety.

\section{Ergonomics Analysis}

Ergonomics is the process of designing or arranging workplaces, products and systems so that they fit the people who use them. According to [12], Ergonomics is the study of the relationship between the workers and the working environment. It is vital for the workers to be concerned and realize the potential ergonomics risk factors 
around their workplace as the consequences are fatal like death and disability.[13] viewed ergonomics as the systematic way of people at work with the objective of enhancing the working situation, the working environment and the tasks performed. Some of the ergonomic practices can be likened to human posture by which people interact with equipment, tools and machines in the workplaces for effective performance and productivity [14]. Such practices are; Stop rapid movement in the electrical workshop, avoid repeated drilling and welding for an extended period of time, use a screw driver instead of a hammer to drive in screw nails, work in proper and comfortable postures, minimize forceful exertion, use suitable work stations, tools and equipment, provide workers with instruction on proper manual lifting techniques, store products such as wire roles, Appropriate work practices encompasses the human practice of designing equipment and work tasks to conform to the capability of the technicians [15].

\section{Statement of the Problem}

Electrical technicians are educated in technical schools, polytechnics, and universities to fix and manage electrical equipment, such as radios and televisions. As a consequence, the aim of training is based on the premise that the difference between expected and actual results, which necessitates training, is caused by deficiencies in expertise, skills, and attitude. (Okorie, 2000). The skill gap created by the Curriculum and new technical advances has caused the required skills for successful maintenance of the new breed of DVD players to continue to elude graduate students of Nigeria Technical and Technological Institutions. Okoye (2013), revealed that most modern electronics suffer from disrepair (poor repairs) in the hands of these maintenance workers due to negligence, and some faults are complicated enough to cause more harm in domestic appliances. For these and other reasons, an ergonomic analysis of work-related musculoskeletal risks associated with electrical hazards among radio and television technicians is needed in Enugu State

\section{Materials and Methods}

\section{Purpose of the Study}

The purpose of the study is to determine the ergonomic analysis of work-related musculoskeletal risks associated with electrical hazards among radio and television technicians. Specifically, study tends to;

- Determine the factors that facilitate electrical hazard among radio and television technicians in Enugu State.

- Determine the factors that prevent electrical hazard among radio and television technicians in Enugu State.

\section{Research Questions}

1. What are the factors that facilitate electrical hazard among radio and television technicians in Enugu State?

2. What are the factors that prevent electrical hazard among radio and television technicians in Enugu State?

\section{Hypotheses}

$\mathrm{HO}_{1}$ : There is no statistically significant difference in the mean scores of workshop attendants, supervisors, and others by electrical hazard prevention factors among radio and television technicians in Enugu.

$\mathrm{HO}_{2}$ : There is no statistically significant difference in the mean scores of attitudes toward equipment handling by workplace structure among radio and television technicians in Enugu.

\section{Methodology}

According to [16] report, a survey analysis design was used; a survey research design is meant to describe in snapshot of data collected from a sample to represent the population which of the data analysis findings can be generalized. The research was carried out in the workplaces of 18 technicians in Enugu State. There were 42 respondents, including 24 technicians and 8 engineers. Workshop and 10 workshop supervisors in Enugu State. The entire population was used because of its manageable size and was considered appropriate for this study. The instrument was validated by three experts, two experts from the University of Nigeria Nsukka and one industrial based supervisor from scientific Equipment Development Institute (SEDI) Enugu State. Reliability of .89 was established using cronbach's alpha coefficient. Questionnaire was used for data collection. It was made up of items of factors that facilitate and prevent hazards among technicians. The items were rated by the respondents on a four rating point scales with responses as follows; Strongly Agreed (SA) 4.00, Agreed (A) 3.00, Disagreed (D) 2.00, Strongly Disagree (SD) 1. The data collected from the respondents were analyzed using Statistical Package. Mean and standard deviation were the analytical tools used to answer the research question while ANOVA was used to test the hypotheses at .05 level of significance.

Data in Table 1 reveal that all the items on factors that facilitate $\mathrm{E} / \mathrm{E}$ hazards of radio and television technicians had their mean above the real limit of 2.50. It depicts that all the items were required of the technicians to observe as it has the capacity to impact technicians and other workers in R.TV workstations. 
Table 1. Mean and standard deviation of respondents on factors that facilitate electrical hazard among radio and television technicians in their workplaces

\begin{tabular}{|c|c|c|c|c|c|}
\hline $\mathbf{S} / \mathbf{N}$ & Workplacestructure & $\bar{X}$ & SD & t-Cal & Sig \\
\hline 1. & The electrical work station is not fitted with appropriate tool filling cabinet & 3.48 & 0.5 & -0.60 & 0.40 \\
\hline 2. & $\begin{array}{l}\text { Electrical technicians lack adequate tools filling cabinets when they carry out } \\
\text { maintenance outside their workstations }\end{array}$ & 3.49 & 0.51 & 1.09 & 0.77 \\
\hline 3. & $\begin{array}{l}\text { Electrical technicians experience musculoskeletal injuries in their work } \\
\text { Station }\end{array}$ & 3.44 & 0.56 & -0.89 & 0.62 \\
\hline 4. & $\begin{array}{l}\text { Electrical technicians experience musculoskeletal injuries during maintenance } \\
\text { outside their workstation }\end{array}$ & 3.43 & 0.57 & -0.23 & 0.65 \\
\hline 5. & $\begin{array}{l}\text { The arrangement of the tools filling cabinets in the repair room of } \\
\text { Electrical technicians are worst arrangement }\end{array}$ & 3.53 & 0.51 & 0.67 & 0.64 \\
\hline 6. & Protective clothing not available most of the time & 3.13 & 0.64 & 0.42 & 0.71 \\
\hline 7 & Electrical technicians are always willing to put on the protective clothing & 3.29 & 0.61 & 0.53 & 0.19 \\
\hline 8 & Electrical technicians drop tools carefully on the floor of their workstation & 3.37 & 0.65 & -0.13 & 0.32 \\
\hline 9 & $\begin{array}{l}\text { Some think it is the supervisor's responsibility to be mindful of hazards in the } \\
\text { workplace and minimize the risk of harm }\end{array}$ & 3.49 & 0.59 & 0.31 & 0.22 \\
\hline 10 & $\begin{array}{l}\text { Some think that it is the technician's responsibility to be mindful of } \\
\text { Hazards in the workplace and minimize the risk of harm }\end{array}$ & 3.51 & 0.52 & -0.35 & 0.92 \\
\hline 11 & $\begin{array}{l}\text { Some think that it is the technician's responsibility to be mindful of } \\
\text { Hazards in the workplace and minimize the risk of harm }\end{array}$ & 3.55 & 0.53 & -1.37 & 0.12 \\
\hline 12 & $\begin{array}{l}\text { Some think that it is everyone's responsibility to be mindful of } \\
\text { Hazards in the workplace and minimize the risk of harm }\end{array}$ & 3.27 & 0.67 & 0.09 & 0.44 \\
\hline 13 & $\begin{array}{l}\text { Training on workplace safety is not a continuous exercise in this } \\
\text { Organization }\end{array}$ & 3.46 & 0.51 & 0.77 & 0.40 \\
\hline 14 & $\begin{array}{l}\text { Workplace safety practices (hazard prevention awareness is not } \\
\text { Priority of this organization }\end{array}$ & 3.47 & 0.51 & -0.17 & 0.73 \\
\hline 15 & Coming in contact with bare conductor which causes electric shock. & 3.43 & 0.49 & 0.36 & 0.93 \\
\hline 16 & $\begin{array}{l}\text { Operating electric machines or equipment without the manuals or } \\
\text { Work permit. }\end{array}$ & 3.42 & 0.64 & -1.19 & 0.98 \\
\hline 17 & $\begin{array}{l}\text { Inappropriate handling and using of hand tools like; pliers, screw } \\
\text { driver, chisel, hammer etc. }\end{array}$ & 3.53 & 0.55 & 0.67 & 0.64 \\
\hline 18 & $\begin{array}{l}\text { Stepping on obstructions left on the floors such as nails, pieces of } \\
\text { Irons or bare conductor. }\end{array}$ & 3.38 & 0.51 & -0.81 & 0.98 \\
\hline 19 & $\begin{array}{l}\text { Using electrical portable power tools such as drilling machines } \\
\text { wrongly. }\end{array}$ & 3.53 & 0.55 & 0.67 & 0.64 \\
\hline 20 & $\begin{array}{l}\text { Coming in contact with moving objects in the R,Tv technicians } \\
\text { Workshops. }\end{array}$ & 3.53 & 0.51 & 0.31 & 0.22 \\
\hline 21 & $\begin{array}{l}\text { Storing chemicals, materials and other equipment in the same place } \\
\text { Carelessly }\end{array}$ & 3.36 & 0.52 & 0.40 & 0.25 \\
\hline 22 & $\begin{array}{l}\text { Lack of maintaining of electrical tools can lead to electric shock or } \\
\text { Burn }\end{array}$ & 3.35 & 0.68 & 0.60 & 0.65 \\
\hline 24 & Cutting irons or wire wrongly in the R,Tv technicians workplaces. & 3.43 & 0.51 & 0.45 & 0.40 \\
\hline 25 & $\begin{array}{l}\text { Postural problems occur due to prolonged static postures and } \\
\text { Working in awkward positions due to incorrect work station set-up }\end{array}$ & 3.42 & 0.57 & 1.04 & 0.64 \\
\hline
\end{tabular}


Table 2. Mean and standard deviation of respondents on factors that prevent electrical hazard among radio and television technicians in their workplaces

\begin{tabular}{|c|c|c|c|c|c|}
\hline $\mathrm{S} / \mathrm{N}$ & Item Statements & $\bar{X}$ & SD & $\mathrm{t}-\mathrm{Cal}$ & Sig \\
\hline 1. & $\begin{array}{l}\text { For working on energized parts, radio and television technicians must wear adequate } \\
\text { personal protective equipment (PPE). }\end{array}$ & 3.64 & 0.57 & 0.14 & 0.41 \\
\hline 2 & Use of filling cabinets in E/E workplaces is acceptable. & 3.47 & 0.59 & 0.04 & 0.22 \\
\hline 3 & In the office, bright light (illumination) avoids E/E risks. & 3.54 & 0.84 & -0.02 & 0.87 \\
\hline 4 & Usage of flexible cords correctly & 3.46 & 0.59 & -1.44 & 0.27 \\
\hline 5 & $\begin{array}{l}\text { Routine inspection and maintenance of electric tools can help avoid E/E hazards in radio } \\
\text { and television studios. }\end{array}$ & 3.44 & 0.65 & 0.03 & 0.06 \\
\hline 6 & $\begin{array}{l}\text { In the workplaces of electrical technicians, calculations for the degree of hazard are } \\
\text { needed. }\end{array}$ & 3.31 & 0.72 & -0.56 & 0.35 \\
\hline 7 & $\begin{array}{l}\text { Workshop training for workers on how to be mindful of hazards are important in the } \\
\text { R,Tv workplaces. }\end{array}$ & 3.34 & 0.58 & -2.57 & 0.82 \\
\hline 8 & Appropriate use of electrical tools for safe working. & 3.19 & 0.65 & -1.57 & 0.98 \\
\hline 9 & $\begin{array}{l}\text { Employees must obey all protective work procedures including safe work } \\
\text { Boundaries and proper labeling of equipment }\end{array}$ & 3.28 & 0.52 & -0.37 & 0.81 \\
\hline 10 & Appropriate separation of hand and power tools on the shelf helps to prevent $\mathrm{E} / \mathrm{E}$ hazards & 3.28 & 0.52 & -0.37 & 0.81 \\
\hline 11 & Technicians should always make use of ladder when working above shoulder height & 3.31 & 0.67 & -0.58 & 0.29 \\
\hline 12 & Employees must use the proper protective equipment for the task & 3.38 & 0.73 & -0.61 & 0.29 \\
\hline 13 & Employees must use insulated tools to avoid electrocution. & 3.34 & 0.55 & -0.44 & 0.77 \\
\hline 14 & $\begin{array}{l}\text { Qualified people must have a written plan that is approved by authorized management if } \\
\text { working on live equipment. }\end{array}$ & 3.48 & 0.51 & -0.67 & 0.64 \\
\hline 15 & $\begin{array}{l}\text { E/E technicians must de-energize all circuits before performing any maintenance on } \\
\text { them. }\end{array}$ & 3.32 & 0.65 & 0.08 & 0.40 \\
\hline 16 & $\begin{array}{l}\text { E/E technicians should not wear conductive articles of jewelry and clothing, such as } \\
\text { watch bands, bracelets, rings, key chains, necklaces, metalized aprons, cloth } \\
\text { With conductive thread, or metal headgear. }\end{array}$ & 3.48 & 0.57 & -0.60 & 0.40 \\
\hline 17 & $\begin{array}{l}\text { Test instruments, equipment \& test leads, cables, power cords, probes, and connectors } \\
\text { must be visually inspected for external defects and damage before the } \\
\text { Equipment is used. }\end{array}$ & 3.49 & 0.51 & 1.09 & 0.77 \\
\hline 18 & $\begin{array}{l}\text { Always Use test equipment to test the circuits \& electrical parts for voltage \& } \\
\text { current }\end{array}$ & 3.44 & 0.56 & -0.89 & 0.62 \\
\hline 19 & $\begin{array}{l}\text { Use safety signs, safety symbols, or accident prevention tags to warn others about } \\
\text { Electrical hazards which may endanger the technicians. }\end{array}$ & 3.43 & 0.57 & -0.23 & 0.65 \\
\hline 20 & $\begin{array}{l}\text { Welders and other workers nearby provided with flash shields, ear muff during } \\
\text { Welding operations }\end{array}$ & 3.34 & 0.58 & -2.57 & 0.82 \\
\hline 21 & $\begin{array}{l}\text { Radio, television technicians should adjust the work station to fit the needs and place the } \\
\text { things they use most often closest to them. }\end{array}$ & 3.19 & 0.65 & -1.57 & 0.98 \\
\hline 22 & $\begin{array}{l}\text { Electrical technicians should be aware of awkward body positions to take during } \\
\text { maintenance. }\end{array}$ & 3.28 & 0.52 & -0.37 & 0.81 \\
\hline 23 & $\begin{array}{l}\text { Employers of R,Tv technicians must provide facilities and a safety program with defined } \\
\text { responsibilities. }\end{array}$ & 3.28 & 0.52 & -0.37 & 0.81 \\
\hline 24 & $\begin{array}{l}\text { Employees must be properly trained and be considered Qualified by the employer } \\
\text { Before handling any tasks. }\end{array}$ & 3.31 & 0.67 & -0.58 & 0.29 \\
\hline 25 & $\begin{array}{l}\text { Only authorized and trained personnel permitted to use welding, cutting or brazing } \\
\text { equipment }\end{array}$ & 3.64 & 0.57 & 0.14 & 0.41 \\
\hline 26 & $\begin{array}{l}\text { Adequate supervision to ensure that employees are following safe machine } \\
\text { Operating procedures }\end{array}$ & 3.47 & 0.59 & 0.04 & 0.22 \\
\hline 27 & $\begin{array}{l}\text { Protective goggles or face shields provided and worn where there is any danger of flying } \\
\text { particles or corrosive materials }\end{array}$ & 3.54 & 0.84 & -0.02 & 0.87 \\
\hline
\end{tabular}

Data in Table 2 reveal that all the items on factors that prevent hazards in the $\mathrm{E} / \mathrm{E}$ workplaces had their mean above the real limit of 2.50 . It depicts that all the items were required by the technicians so as to prevent hazards in the $\mathrm{E} / \mathrm{E}$ workplaces

\section{Discussion}

The aim of this study was to undertake an ergonomic analysis of work-related musculoskeletal risks linked to electrical hazards among radio and television technicians 
in Enugu State. Despite the fact that there are few researchers on electrical hazards in radio/television technicians in general, the high frequency of electrical hazards and musculoskeletal risks identified in this study is consistent [17]. It is also in agreement with [18].which revealed a high prevalence of musculoskeletal pains and electrocution among workers involved in workshop maintenance which include improper handling of power tools, inappropriate work station structure, careless handing of hand tools, unusual and restricted postures, repetitive and vibration. This example is in conformity with [19] who reported an increased prevalence of back pain among workers in the radio/television workstation. The findings are also in agreement with [20], who stated that a single accident can mean enormous financial loss to both workers and employers and [21] who stated that low back pain is a common WMSD which about $60-80 \%$ of all individuals will experience at a certain stage in their lifetime. The impact of the factors that facilitate electrical/electronic hazards are more on technicians, because it can be attributed to the fact that maintenance work entail repetitive, forceful motions, use of vibratory tools and equipment, lack of filling cabinet, careless dropping of power and hand tools together, use of ordinary wires in the presence of flammable material, Without any protection, cables run over the floor or walkways, Ordinary electrical equipment, overloading an equipment, switching wet equipment, and incorrect usage of flexible extension cords are all examples of extensions/adaptors that are not fed from an installed socket point. This finding is in conformity with [22] in which are relationship existed between these factors.

\section{Conclusions}

There is a high occurrence of hazards and work-related musculoskeletal risks among radio/television technicians in Enugu State. Performing the same activity over and over, continuing to work while ill, hurt, or electrocuted, terrible posture, and a bad work place structure with the way objects are arranged were the most troublesome factors for the respondents. Good workshop with appropriate filling cabinet should be made available. Seminars and orientation programmes should be organized regularly for the technicians and other workers to enlighten them on the avoidance and coping strategies of WMSRs so as to promote their efficiency in the workplace. There should be ergonomic intervention at the workplace so as to minimize the occurrence of work related musculoskeletal problems among radio/television technicians in Enugu State.

\section{REFERENCES}

[1] Prevention report, "Work-related musculoskeletal disorders:
European Agency for Safety and Health at Work", A European Campaign on Musculoskeletal Disorders, vol., no91-98. Pp52(2), 2008.

[2] Omokhodion F. O and Sanya A. O. "Risk factors for low back pain among office workers in Ibadan, South WestNigeria", Medical Occupation Journal, vol. 53, no 287-289, 2003.

[3] Ogbuanya T. C. \& Shetima A, "Retooling index of professional electrical teacher for maintenance of electrical laboratory equipment in technical colleges in northern Nigeria", Nigeria Vocational Association Journal (NVAJ), vol.20 (2), pp. 222-232,2014.

[4] Vocational Education and Training "Plan for the Electrical and Electronic Engineering Industry", Tertiary and Vocational Education Commission, Sri Lanka, 2012.

[5] Kadiri, S. A (2008). Safety handbook for engineering and allied professionals Lagos.Zwe-chord publishers.

[6] Eraut, 2000 and Avis, 2010, "Development of measures to control work-related musculoskeletal risks" Uwais: Ireland.

[7] Aarkrog, 2005, "Analysis of hazards among radio and television technicians. Akaberg Press: France.

[8] AmadiC., "Health, safety and environment course”, SAGIF Publishing, 2012.

[9] Rongo, L. M.B., "Are workers in Dar-es-Salaam aware of occupational ergonomics principles?" African Newsletter on Occupational Health and Safety, vol. (15), pp. 14-16,2005.

[10] Miller, I. O. "Work skills improvement needs of graduates of technical colleges in machine shop practice for demand driven employment in South West Zone of contemporary Nigeria", Nigerian Vocational Association Journal, vol.15(1), pp.18-27.

[11] Uhl, D., "Turn up to learn: Leadership in high-hazard industries", Aubery Daniels International Inc, 2012.

[12] OSHA3125,"Ergonomics: The Study of Work.”,U. S. Department of Labor Occupational Safety and Health Administration, 2000.

[13] Mokdad, M., "The quality of higher education: from TQM to Ergonomics" Paper presented on the international seminar on quality in higher education organization in Bahrain University, from 11 through 13 April 2005", Manama, Bahrain American Public health Association, 2005.

[14] McSween,T.E., “TheValues-Based Safety Process”, John Wiley \&Sons: New Jersey, 2003.

[15] Perdue, S., "Beyond observation and feedback: Integrating behavioural safety principles into other safety management systems" Proceedings of the 2000 American Society of Professional Engineers (ASSE) Conference and Exposition, 2000.

[16] OkorieJ. U., “Developing Nigeria's workforce. Calabar", John Wiley\&Sons: NewJersey,2000.

[17] Okoye, K. R. E. and Okwelle, P.C., "Complex mix of socio-political synergy to technical vocational education and training (TVET) in Nigeria", Kuwait Chapter of 
Arabian Journal of Business and Management Review, vol. 3(3), pp.28-40,2013.

[18] OkorieJ. U.,“ Developing Nigeria's workforce. Calabar”, John Wiley\&Sons: New Jersey, 2000.

[19] Okoye, K. R. E. and Okwelle, P.C., "Complex mix of socio-political synergy to technical vocational education and training (TVET) in Nigeria", Kuwait Chapter of Arabian Journal of Business and Management Review, vol. 3(3), pp. 28-40, 2013.

[20] Amadi C.,"Health, safety and environment course", SAGIF Publishing, 2012.

[21] Morken,T.,Riise,T.,Moen,B.,Bergum, O., Hauge, S. H.,
Hollen, S., Langedrag, A., Olison, H. O., Pederson, S., 2014.

[22] Edwin, M., Tappin, D. and Bentley, T. "Musculoskeletal disorders in the New Zealand log Sawmilling”, 2002.

[23] Waddell, G. and Burton, A. K., "Occupational health guidelines for the management of low back pain at work", Occupational Medicine, vol. 51, pp. 124-135, 2001.

[24] Miller, I. O., "Work skills improvement needs of graduates of technical colleges in machine shop practice for demand driven employment in South West Zone of contemporary Nigeria" Nigerian Vocational Association Journal, vol. 15(1), pp. 18-27, 2008. 